\title{
The Contribution of the Brazilian Government's Integrated System for Financial Administration (SIAFI) to Promotion of Horizontal Accountability: The Perception of Users
}

\author{
Joaquim Rubens Fontes Filho \\ Fundação Getúlio Vargas - EBAPE \\ Gladston Guimarães Naves ${ }^{\Omega}$ \\ Fundação Getúlio Vargas - EBAPE
}

\begin{abstract}
This article examines the contribution of the Integrated System for Financial Administration (SIAFI) of the Brazilian government to the promotion of horizontal accountability of the federal public administration in the perception of the system's distinct groups of users. Based on the theoretical framework and analysis of documents on the SIAFI and the rules on public administration, we defined three dimensions to assess accountability - transparency, rendering of accounts and attribution of responsibility - operationalized through an online questionnaire with responses scored on a Likert scale. This questionnaire was sent to four groups of system users - managers, operators, control agents and investigation agentslinked to 128 entities of the federal government. The treatment and analysis of the results through factor analysis and comparison of groups allowed characterizing an overall perception of the efficacy of the SIAFI in promoting horizontal accountability, despite variations in this perception within the constitutive dimensions defined, according to the users' origin and their relationship with the system.
\end{abstract}

Keywords: Accountability. Public administration. SIAFI.

*Author for correspondence:

${ }^{\dagger} \mathrm{PhD}$ in Administration from the Brazilian School of Public and Business Administration of Getulio Vargas Foundation (EBAPE)

Institution: Professor at EBAPE

Address: Praia de Botafogo, Botafogo. RJ - Brazil

E-mail: Joaquim.rubens@fgv.br

Telephone: (21) 37995753

\footnotetext{
${ }^{\Omega}$ Master's in Public Administration from the Brazilian School of Public and Business Administration of Getulio Vargas Foundation (EBAPE) Institution: Researcher at EBAPE

Address: Praia de Botafogo, Botafogo - RJ - Brazil

E-mail: gladston.ggn@dpf.gov.br

Telephone: (61) 20248457
}

Note from the Editor: This article was accepted by Emerson Mainardes 


\section{INTRODUCTION}

he concept of governmental accountability is basically related to the ideas of rendering of accounts and attribution of responsibility, also encompassing the duty of transparency, of publication of public acts and of providing means for the population to participate in the decision-making processes of the public administration (AKUTSU, 2005). However, it is insufficient to limit the amplitude of the concept of accountability to the relationship of the public administration with society, given the insufficiency of available mechanisms for enforcement, control and attribution of responsibility, particularly in the case of Brazil. Accountability cannot be restricted to the agency relations between the bureaucracy and citizens, or between politicians and the bureaucracy, given the existence of information asymmetries, absence of institutional mechanisms for reward and punishment and pulverization of the action of the government into multiple actors with often dissonant objectives (PRZEWORSKI, 2003).

If the understanding of the concept is limited to a mechanism for democracy that represents control of rulers by the ruled (ANASTASIA; MELO, 2002), it configures a vertical relationship of rendering of accounts and control, or multiple principal-agent relationships, according to what O'Donnell (1991) defined as vertical accountability (VA). For him, it is also necessary to recognize the existence of a horizontal dimension in accountability (HA), characterized as lateral control of the bureaucracy itself, exemplified by the existence of government entities with oversight powers (O’DONNELL, 1999). According to Louzada, Fontes Filho \& Rezende (2010), this form of accountability is based on a system of checks and balances, of mutual control and evaluation between the branches of government, such as the role of audit tribunals and ombuds offices, identified with greater precision in the relationship of the three branches of government, where the executive branch is overseen by the legislative branch and both are responsible to the judiciary.

The change in a paradigm of public governance based on a single vertical and hierarchical integration to plural governance, with multiple interdependences among actors, is defined by Osborne (2006) as the new public governance. It refers to an environment of greater autonomy of public actors, formation of networks and structuring of interorganizational relationships. However, while this environment can bring gains in flexibility, it can also make accountability diffuse, particularly if based on a vertical hierarchical model.

In this context, according to Schillemans (2008), new forms of accountability are 
necessary, and the strengthening of HA can be a suitable solution to deal with the size and complexity of a more fragmented public administration, complementing VA. For him, HA allows addressing peers, equals, or other external stakeholders to the hierarchical relationship between the government and an agency.

Bovens (2005) defines accountability as "a social relationship in which an actor feels an obligation to explain and to justify his or her conduct to some significant other" (p. 184). This definition allows a precise understanding of the importance of peers in HA to go beyond a system of checks and balances. The effectiveness of this accountability is associated with the capacity of these peers to know and understand the actions of the others.

In the Brazilian case, an important instrument to promote HA — based on monitoring and control of all budgetary, financial, asset management and accounting execution of the federal government - is the Integrated System for Financial Administration (SIAFI), developed by the National Treasury Secretariat (STN), the central accounting entity of the federal government, together with the Federal Data Processing Service (Serpro). The SIAFI is a strategic tool for control of the state because it makes available the daily records of information stored and allows monitoring the budgetary, financial, asset management and accounting execution of the various central, sectorial and execution entities of the federal executive, legislative and judicial branches. The integration of the financial programming promoted by the SIAFI facilitates the planning process, because the authorized users register their documents and make consultations in standardized form among the various management units.

With the SIAFI, the attribution of responsibility and rendering of accounts are strengthened, since the system allows the registration and disclosure of the acts and facts of the government's budgetary and financial management. For Piscitelli \& Timbó (2010), the SIAFI permits developing the fundamental conditions for the analytic accounting bodies to have the capability to analyze and control the accounting outputs, making their work more effective. According to Ribeiro Filho (1997), the SIAFI has become consolidated as a management control instrument.

Considering the importance of the SIAFI as an instrument for socialization of budgetary, financial, asset management and accounting execution of the various areas of government, this study seeks to identify the contribution of the system to the promotion of HA in the ambit of the federal public administration in Brazil, according to the perception of its users, based on aspects of usability, scope and functionalities. 
A previous study of the opinions of a sample of SIAFI users showed that the level of user satisfaction is a valid metric to understand the performance of this system (SUZART, 2013). In this study, we extend this performance measurement to include a dimension of effectiveness, reflected by the contribution to HA, assessed based on the perception of users from distinct groups, classified in relation to their function, time of working in public service, position held and use of the system.

\section{CONTEXT AND THEORETICAL FRAMEWORK}

This section first presents the SIAFI as an instrument for transparency and control of the federal public administration and then considers the possibilities and limitations of evaluating the effectiveness of information systems, focusing specifically on the question of accountability, considered to be one aspect evidencing the effectiveness of this system and its forms of appreciation. The dimensions associated with the concept are presented from the standpoint of theories from the field of public administration and are situated, in the Brazilian case, according to the legislation on its application. The definitions and characteristics of the SIAFI are presented to enable understanding the functionalities that contribute to the promotion of accountability.

\subsection{ACCOUNTABILITY AND THE INTEGRATED SYSTEM FOR FINANCIAL ADMINISTRATION (SIAFI)}

Delimiting the objectives, means and scope of accountability is not trivial, since the very understanding of the concept has varied considerably over time (WEBER, 1999). In Brazil the discussion of accountability started with the instigation of Campos (1990), in an article in which he asked how and when this concept could be translated, in all its meaning, to Portuguese. Twenty years later, Pinho \& Sacramento (2009) revisited the discussion, asking whether this moment had arrived. According to them, despite the advances in the ensuing period, Brazil was still far from having a true culture of accountability. Although there is no word in Portuguese that expresses its exact definition, the concept is commonly understood as related to the control and oversight of and attribution of responsibility to public agents. According to Coelho (2000), when a person or entity is responsible for decisions and the implications of his or her actions and inactions, he or she is considered accountable, in a model of moral responsibility that seeks to protect the person's reputation and integrity.

As mentioned before, O'Donnell (1998) classifies accountability into vertical and horizontal. The first is promoted by the electoral process, through the public's choice of those to occupy positions in institutions of the state, as well as by mechanisms for citizen 
complaints and regular media coverage of allegedly illegal acts of public authorities. In turn, horizontal accountability involves the control exercised by a network of governmental agencies that have the legal right and power to supervise, control and prevent actions, apply legal penalties and/or impeach/dismiss officials deemed responsible for actions or omissions classified as criminal, in the form of checks and balances between the executive, legislative and judicial branches. In Brazil, at the federal level the Federal Audit Tribunal (TCU), Office of the Comptroller General (CGU) and other specific federal entities exercise the functions of control and oversight as a form of HA. The SIAFI offers resources for control and oversight to other forms of intra-governmental accountability, from the perspectives of legislative, judicial, administrative-financial and social control as well as control of results (ABRUCIO; LOUREIRO, 2005).

The legislative control over the executive branch by means of the SIAFI consists of the oversight, evaluation and monitoring of budgetary execution. The system also permits congressional committees to exercise administrative-financial control of public resources. In For judicial control, the SIAFI has a secure base of information to produce court filings regarding budgetary and financial mismanagement by public officials.

The system also enables control of results, by means of transparency and visibility of the performance of government programs. Social control, as a VA mechanism, involves the participation of citizens as watchdogs of government actions. For this, the actions of the federal officials responsible for spending public moneys are registered in the SIAFI, and this information must be published for access to all citizens, as required by Complementary Law ${ }^{1}$ 101/2000, better known as the Fiscal Responsibility Law (LRF). ${ }^{2}$

The Transparency Portal of the federal government is an example of the application of these rules, because it supplies to society, based on the SIAFI, detailed data on the federal government's budgetary and financial execution, updated daily. The imposition by the LRF of the supply of information by means of governmental portals opens the way to use the information so obtained by society itself as well as by internal and external control bodies. This imposition is in line with an international trend, starting in the 1990s, of expanded use of

\footnotetext{
${ }^{1}$ A complementary law (lei complementar) is an enabling law of constitutional provisions.

${ }^{2}$ Besides the LRF, the publication of information is required by Complementary Law 131/2009, which added provisions to the LRF determining the online posting, in real time, of detailed information on the budgetary and financial execution of the federal, state, Federal District and municipal governments; and by Law 12,527/2011, which regulates access to the information referred to in Art. 5, numeral XXXIII, Art. 37, § 3, numeral II and Art. $216, \S 2$, of the Federal Constitution and revoked Law 11,111/2005 and certain provisions of Law 8,159/1991.
} 
information and communication technologies (ICTs) to strengthen accountability and transparency (ZANELLO; MAASSEM, 2011).

The Brazilian legal system also contains various other constitutional and infraconstitutional mechanisms related to attributes of accountability. The Federal Constitution assures access to information, requires public agents to render account of their actions, defines rules regarding oversight of accounting, budgetary and operational matters (BRASIL, 2010b) and also provides for judicial control, which according to Abrucio;\& Loureiro (2005), is a form of attributing political responsibility within government. The infra-constitutional rules assure the accountability of the public sector by requiring transparency of the administrative process, attribution of responsibility in fiscal management, effective mechanisms for popular participation (e.g., public hearings) and rendering of accounts by public officials (BRASIL, 1998, 1999, 2000a, 2010c).

For the purpose of rendering accounts to keep the public informed about the government's political and administrative decisions, the concept of administrative transparency has been established (MARTINS JÚNIOR, 2004). In this respect, Law 9,755/1998, better known as the Public Accounts Law, requires the TCU to maintain a website (www.contaspublicas.gov.br) to give transparency to government activity, by disclosure of contracts and the budgetary, financial, asset management and accounting execution of the federal, state, Federal District ${ }^{3}$ and municipal governments (BRASIL, 1998).

Law 9,784/1999, which regulates the federal administrative process, establishes rules to protect the rights of individuals, companies and other legal entities and to assure better attainment of government objectives, through observance of transparency, among other mechanisms (BRASIL, 1999).

The federal government, until 1986, was plagued by various administrative problems in relation to the working methods used and the long delay in providing information, hampering adequate management of public resources and preventing the preparation of a unified budget (CASTRO; GOMES, 2002; CASTRO; GARCIA, 2008). The SIAFI, implemented in 1987, was a response to the need for up-to-date information to streamline the decision-making process and integrate the systems of financial programming, budgetary execution and internal control, by providing reliable and accurate information to all levels of the federal public administration.

\footnotetext{
${ }^{3}$ The Federal District, location of the nation's capital, Brasília, is a hybrid with characteristics of a municipality and state regarding taxing powers, congressional representation and internal governmental organization.
} 
Developed on accounting bases, the SIAFI integrates various systems: the federal budget system, which demonstrates the origin and allocation of revenues; the financial system, which evidences the cash flow; the asset management system, which presents the composition and situation of federal property and other assets; and the compensation system, which indicates the net effects of the government's rights and obligations (SLOMSKI, 2003). The SIAFI therefore shows the situation of all those responsible for collection of revenues, execution of expenditures and management of the assets belonging to the entities of the federal government, by means of their accounts, to enable evaluation of their managers. One limitation to the promotion of VA is that direct access to the information in the SIAFI is only allowed to authorized users, normally civil servants and political agents. Society only has access to this information on a second-hand base, when revealed by governmental portals.

The SIAFI has provided greater transparency of the actions of the federal government regarding public spending, by reducing the information asymmetry between public actors. Furthermore, although access to the system is limited to public agents, it is still important to consider that "the adequate performance of horizontal accountability mechanisms positively affects the exercise of vertical accountability, in the electoral plane, by reducing the information asymmetry between actors" (ANASTASIA; MELO, 2002, p. 29). Thus the information contained in the system serves a large number of users and reflects the essence of the government's actions and its objectives, the persons responsible for these actions and their costs (CASTRO; GARCIA, 2008). The unified accounting template for the federal government allows registration of governmental actions and generates various reports to disclose useful information to interested parties. Besides this, the system incorporates all the reports and financial statements required by Law 4,320/1964 and the Fiscal Responsibility Law (LRF) that are subject to mandatory publication.

\subsection{EVALUATION OF THE EFFECTIVENESS OF INFORMATION SYSTEMS}

According to Olivieri (2006), improvement of the SIAFI was one of the most important positive results of the reform brought by the Master Plan for Reform of the State of 1995, by filling in a gap in the Brazilian public administration, namely the lack of consolidated information. For the author, the control over the bureaucracy is a fundamental aspect of the Weberian bureaucratic theory, and is also central to the thinking connected to the New Public Management, given the "emphasis of its discourse on accountability and on the results of public management, since results need to be measured, evaluated and in the final analysis controlled, whether or not through bureaucratic structures" (p. 7). 
However, the consolidation and provision of information alone do not necessarily mean a system will be successful or effective. According to Suzart (2013), few studies have examined what makes an information system successful or how to assess this success. Bokhari (2005, p. 211) considers that an information system can be considered successful if it satisfies the needs of its users and meets the objectives and goals of the organization. In this respect, the contribution of the SIAFI to the promotion of HA can be considered a measure of the success or effectiveness of the system. Nevertheless, this contribution must be perceived as one of the multiple dimensions related to this dependent variable of effectiveness, and it is hard to isolate its effect versus other factors, such as the capability of attributing responsibility and applying the corresponding punishments.

The problem of assessing the effectiveness of information systems has been recognized for over 30 years. As described by DeLone \& Ephraim (1992), although the effectiveness of a system is, in the overall perspective of the organization, the measure of greatest repercussion and interest, its evaluation had been avoided in studies up to that time by the difficulty of isolating the effects of information technology from other effects that influence the organization's performance. They advocated that the importance of defining the dependent variable of a system's success cannot be underestimated, since absence in this sense would make any study merely speculative. For Masoner, Lang \& Melcher (2011), the quality of the information, quality of the system (ease of use), perceived utility and satisfaction of users are variables that can be used to assess the success of information systems, but each one represents a single concept, making success a multidimensional concept.

Petter, DeLone \& McLean (2012) evaluated the changes in the conception of success of information systems since 1950 and their evolution in each decade. Particularly since 2010, as these systems have become more personal and personalized, the perception of user groups or individuals has been growing more variable. Therefore, to measure the success of an information system requires considering not only the support offered to users, but also separating the impacts due to the system from those related to other variables. The main focus in measuring the success of a system continues to be based on inputs and processes instead of the results. Stakeholders generally believe that assessing the success of information systems is something expensive and difficult, so the assessments tend to be concentrated in the capability of the project to meet requirements of time, scope and functionality.

Romzek \& Johnston (2005), in dealing with government social service contracting, defined the effectiveness of accountability as the capability of a government agency to design, 
implement, manage and achieve accountability in its contracts, which involves obtaining timely and accurate reports and using information to evaluate performance, correct deficiencies and keep contractors in line. To analyze the effectiveness of accountability, Amirkhanyan (2011) operationalized the construct through six items used to measure the perceived level of effectiveness and independent variables related to the collection, monitoring and assessment of information.

\subsection{DIMENSIONS OF ACCOUNTABILITY}

Evaluating an information system meant to enhance transparency and control in the public sector should certainly consider the contribution of accountability as a dependent variable, within a multidimensional logic (MASONER; LANG; MELCHER, 2011). Three dimensions have been utilized to define accountability: transparency, rendering of accounts and attribution of responsibility (CENEVIVA, 2006; VALENTE, 2004). Transparency involves the visibility of the acts of public sector agents and evidences the access to information and its comprehension; rendering of accounts covers the social obligation to provide information about the actions of public agents; and attribution of responsibility for these actions assigns liability to those that disobey the rules and imposes penalties as set forth in law. These dimensions are discussed in more detail below, looking to validate their operationalization and the indicators used.

\section{(a) Transparency}

According to Valente (2004), administrative transparency does not by itself assure the functioning of accountability mechanisms, but it is not possible to adopt such mechanisms without it. Transparency represents the duty of agents to report their actions regarding management to interested parties regardless of a legal or regulatory requirement (IBGC, 2009).

Public management is done through access to information. In the public administration, a high degree of administrative transparency is a determining factor to assure a state of law (MARTINS JÚNIOR, 2004). As pointed out by Przeworski (2005), from the standpoint of the principal-agent relationship, the lack of complete information to the principal (citizens) about the activities of the agent (the state) causes information asymmetry, which to be minimized requires that other independent entities work to improve the quality and quantity of information provided to citizens. For Castro (2010), the existence of a commitment to transparency of government actions requires correct and effective accounting records. 
Slomski (2007) stated that the LRF made a major contribution to the transparency of government acts and stressed that internal and external communication results in a feeling of trust in government, both internally and externally. For true transparency, access to public information should involve all budgetary, financial, asset management and accounting execution of the government. The information disclosed should be useful to all interested parties, regardless of a specific legal provision. Trust in information promotes questions and tests and does not raise doubts by those that use it. This attribute promotes the acceptance of information by users who employ it in their decisions. Information should be correct, covering all relevant elements, and its content should agree with its title. Therefore, the veracity, completeness and pertinence of content are the base for the trustworthiness of information (CASTRO; GARCIA, 2008).

\section{(b) Rendering of accounts}

The accounting information produced by the SIAFI can be detailed or grouped analytically or synthetically. According to Castro \& Garcia (2008), such information serves as operational support for public managers. Administrative control of accounts is based on analytic information, while synthetic information, with management character, helps in rendering accounts to internal and external control entities. The examination and judgment of the annual accounts of public agents at the federal level are exercised by the Federal Audit Tribunal (TCU), which besides exercising judgment over the management of those responsible for administering federal moneys, issues orders and imposes penalties (CASTRO, 2010). Its competencies are set forth in Articles 33, $§ 2,71$ to 74 and 161, sole paragraph, of the Federal Constitution.

The accounts presented by the President of the Republic in the General Federal Balance Sheet (BGU) and by other public agents, and access to this information, enable control, oversight and monitoring of the administrative actions of the public sector.

(c) Attribution of responsibility

For Campos (1990), accountability includes the strict liability of a person or organization to others. According to Mosher (1968), citizens are exposed to potential risks of the bureaucracy when there is no effective control or penalties applicable to civil servants. The attribution of responsibility to a government, according to Przeworski (2005), occurs only if citizens have political discernment and vote only for candidates with a track record of acting according to the collective interest. 
The LRF provides various penalties for mismanagement of public resources and led to the enactment of Law 10,028/2000, which deals with crimes against fiscal responsibility. These penalties range from loss of office (by impeachment in the case of elected officials and the administrative dismissal process for career civil servants), ineligibility to hold public offices or positions for up to five years, fines or jail.

The TCU, in judging the accounts of public agents, must assure due legal process, meaning the right of rebuttal and ample defense. When the TCU detects indications of irregularities in its analysis, it carries out further investigations, holds public hearings or summons the parties in question to provide clarification, under pain of judgment in absentia. The authority of the TCU is based on the principle that to attribute responsibility to public agents, the state must have tools for society and other public agents to control, oversee and investigate acts and identify those responsible for wrongdoing.

\section{RESEARCH METHODOLOGY AND ANALYSIS OF THE RESULTS}

To operationalize the three constructs related to accountability, we first analyzed the Web Manual of the SIAFI (SIAFI, 2011) to identify and understand its functionalities and to prepare the survey instrument. The SIAFI Web Manual contains procedures for consultation and visualization of the content, with functionalities for navigation and text searches. We investigated the variables associated with the dimensions of the three constructs by using the text search resource, through key words, combined with the asterisk $(*)$ to substitute unknown or generic characters, to allow a comprehensive search for each term and its variations.

Because the SIAFI serves a variety of users, the field research contemplated four groups: system managers (civil servants of the STN), control agents (staff of the CGU and TCU), investigative agents (technical experts of the Federal Police Department - DPF) and operators (users authorized to conduct consultations and/or issue documents).

The survey instrument was divided into two sets of specific questions. The first aimed to characterize the users so as to relate these characteristics to their evaluation of the system, by requesting information on their education, posting, profile and experience in using the system, its usability and functionalities (questions 1,2, 3 and 4). The second set included questions formulated to capture the users' assessment regarding the HA offered by the SIAFI (questions 5, 6 and 7), representing the operationalization of the three constructs: transparency, rendering of accounts and attribution of responsibility, respectively. We used a balanced Likert scale of 4 points, chosen to reduce bias in the responses. This is considered the most parsimonious scale (HINKIN, 1998) and forces discrimination in the responses by 
not including a neutral point in the scale (GARLAND, 1991). The questions posed in the questionnaire, to assess the agreement of the respondents with the statements on the contribution of each indicator, scored as none, little, large or very large, are presented in the Appendix.

Based on the definitions of Malhotra (2001), we sought to validate the scale related to the HA promoted by the SIAFI by defining the constructs discussed in the theoretical framework section, also following a deductive process for generation of items proposed by Brahma (2009) and the knowledge of one of us as an operator of the system (validity of content), while we tested the one-dimensionality of the constructs and convergent and discriminant validity by factor analysis (presented in the results section, which follows). The definition of the research universe was based on a study carried out in the SIAFI Management system in April 2011, which identified the budgetary allocations to 255 federal entities. In composing the sample, we chose the entities most representative of the population of interest, formed by management, control and investigation agents and operators. According to Malhotra (2001), this type of sample depends on the judgment of the researcher, according to his or her convenience and experience.

The questionnaire, constructed in the SurveyMonk software, was sent in April 2011 via Internet to all users of the 128 federal government entities that engage in acts of budgetary, financial or asset management or control acts, denominated Management Units. We received 287 forms in response, $0.4 \%$ of the universe of 69,093 SAIFI users. Table 1 presents the distribution of the population and the sample among the distinct categories of respondents. Despite the non-random nature of the sample and the operational limitation to control the selfselection by the respondents, which was reflected in the different percentages, the relative order of the groups' populations was reflected in the sample.

Table 1: Profile of the Population and Sample

\begin{tabular}{l|r|r|r|r}
\hline \multirow{2}{*}{ Profiles } & \multicolumn{2}{c|}{ Population } & \multicolumn{2}{c}{ Sample } \\
\cline { 2 - 5 } & \multicolumn{1}{c|}{ Number } & \multicolumn{1}{c}{$\%$} & Number & \multicolumn{1}{c}{$\%$} \\
\hline System managers (STN employees) & 123 & 13.8 & 17 & 5.9 \\
\hline $\begin{array}{l}\text { Control agents (CGU and TCU } \\
\text { employees) }\end{array}$ & 2,590 & 2.3 & 59 & 20.5 \\
\hline $\begin{array}{l}\text { Investigation agents (PCF/DPF } \\
\text { employees) }\end{array}$ & 151 & 13.2 & 20 & 7 \\
\hline System operators & 34,627 & 0.6 & 191 & 66.6 \\
\hline \multicolumn{1}{c|}{ Total } & & & 287 & 100 \\
\hline
\end{tabular}

Source: SIAFI (2011) and sample data. 
The responses to the first group of questions were analyzed to check for differences in the characteristics of the groups of users and the respective assessments on the usability and functionality of the system. These were grouped into factors by factor analysis. The responses to the second set of questions, with assessment of the HA permitted by the system, were also compared among the groups and then factors were extracted to reduce the dimensionality of the constructs, by factor analysis with varimax rotation. In the third step of the method, multiple linear regression was applied to check the influence of the factors from the first set of questions on the factors (assessments) of the second set.

The data from the two sets were not normally distributed according to the KolmogorovSmirnov test $(\mathrm{p}<0.05)$, which indicated the need to use nonparametric tests for comparison between the groups of users, both in the characterization and evaluations. For this purpose we used the Kruskall-Wallis followed by the Mann-Whitney test.

The applicability of the factor analysis was verified by the Kaiser-Meyer-Olkin (KMO) index, while the reliability of the factors was evaluated by Cronbach's alpha (Malhotra, 2001) and the means of the factors between the profiles of users were compared by analysis of variance $(A N O V A)$. Finally, the Bonferroni test $(p<0.05)$ was applied to check for any significant difference between the profiles (Pimentel-Gomes, 2009).

The regression utilized the forced entry method (ENTER), with the dependent variables being the factors related to the perception of accountability and the independent explanatory variables being the characterization of the users, their knowledge of the system and perception of usability. The categorical variables related to the profile - schooling level, area of expertise and entity of posting - were codified as dummies ( 0 or 1$)$ and included in the regression as independent variables.

\subsection{CHARACTERIZATION OF THE USERS AND ASSESSMENT OF THE OPERATIONAL ASPECTS OF THE SIAFI}

This section presents the comparison of the user groups and the factor analysis of the usability and the respondents' knowledge of the system.

\section{(a) ) Characterization of the users}

The variables time of public service, time of holding the current position or function and time of using the SIAFI were compared among the user profiles. In relation to time in public service, the Kruskal-Wallis test indicated a significant difference in the user profiles $(p=0.282)$, which also occurred regarding the time of holding the present position $\quad(p=0.199)$. 
Regarding time of using the system, the results indicated that the control agents had more time using the system than the other groups $(\mathrm{p}=0.001)$. This difference, however, does not necessarily indicate more experience of the control agents with the system, because this also depends on the number of functions used and the frequency of use.

\section{(b) Assessment of the usability of the SIAFI}

The results showed that the control agents are significantly more critical in relation to ease of access and operation of the system, the hours of functioning, the quality of the user manual, online help desk and structured reports and their production and the flaws in the system. In all of the questions regarding usability of the system that presented significant differences in the responses, the control agents assessed the SIAFI more negatively than users with other profiles.

The factor analysis of the variables related to usability of the SIAFI, after excluding commonalities smaller than 0.5, which can bring insufficient explanation (Hair Jr. et al., 2005), presented a KMO index of 0.788 and generated four factors (Table 2):

Table 2 - Factors Evaluating the Usability of the SIAFI

\begin{tabular}{|c|l|c|c|}
\hline \multicolumn{1}{|c|}{ FACTORS } & \multicolumn{1}{|c|}{ VARIABLES } & LOADING & ALPHA \\
\hline $\begin{array}{c}\text { F1 - Use of help desk and } \\
\text { reports of the system }\end{array}$ & The online help desk responds to my doubts promptly. & 0.830 \\
& $\begin{array}{l}\text { The SIAFI Web Manual answers most of my doubts. } \\
\text { It's easy to produce reports in the SIAFI. } \\
\text { The structured reports meet the needs of my work. }\end{array}$ & 0.788 & 0.678 \\
\hline $\begin{array}{c}\text { F2 - Functioning, facility } \\
\text { of access and operation }\end{array}$ & The hours of operation meet the needs of my work. & 0.654 \\
\hline $\begin{array}{c}\text { F3 - No need for a SIAFI } \\
\text { training course and } \\
\text { training in public } \\
\text { accounting }\end{array}$ & The system is easy to operate. & 0.803 \\
\hline $\begin{array}{c}\text { F4 - Flaws in the system } \\
\text { It is not necessary to have knowledge of public accounting to operate it. }\end{array}$ & 0.682 & 0.683 \\
\hline & It often presents failures. & 0.522 \\
\hline
\end{tabular}

The Cronbach's alpha values calculated for the factors involving assessment of the system's usability indicated strong reliability for the first and second factors, as demonstrated in the previous chart. The result, however, indicated weak reliability for the third and fourth factors. The Bonferroni test showed a significant difference in factors 1 and 2 between the groups $(\mathrm{p}<0.05)$. In this respect, the more critical vision of the control agents evidenced in the descriptive study was confirmed in the consideration of factors 1 (use of help desk and generation of reports) and 2 (functioning and ease of access and operation).

\section{(c) Level of knowledge of the functionalities of the SIAFI}


In the aspect related to the functionalities of the SIAFI, the self-evaluation of the respondents regarding their knowledge was very heterogeneous among the groups, with the managers and operators indicating better knowledge and the control and investigation agents expressing less knowledge. It should be mentioned that not all the functionalities are customarily used by the various respondent groups, which can explain this difference, such as the functionalities involving rendering of accounts about cooperation agreements between government entities, which are better known to the control agents. The factor analysis of these variables presented a KMO index of 0.907 and allowed extracting four factors. The functionalities that helped transparency, rendering of accounts and attribution of responsibility concomitantly are grouped in one of these factors, because the level of knowledge is near in all of the constructs. The dimension rendering of accounts about cooperative agreements is segregated.

Table 3 - Factors of the Level of Knowledge of the Functionalities of the SIAFI

\begin{tabular}{|c|c|c|c|}
\hline FACTORS & VARIABLES & $\begin{array}{l}\text { LOADIN } \\
\text { G }\end{array}$ & $\begin{array}{c}\text { ALPH } \\
\text { A }\end{array}$ \\
\hline $\begin{array}{c}\text { F1 - Functionalities } \\
\text { of transparency }\end{array}$ & $\begin{array}{l}\text { Demonstra module (accounting statements) and its transactions } \\
\text { Conincons transaction (consultation of inconsistencies - others) } \\
\text { Conevento transaction (event consolation) } \\
\text { Concontir transaction (consultation of accounts to regularize) } \\
\text { Conconta transaction(consultation of the accounting template) }\end{array}$ & $\begin{array}{l}0.726 \\
0.696 \\
0.666 \\
0.664 \\
0.627\end{array}$ & 0.951 \\
\hline $\begin{array}{c}\text { F2 - Functionalities } \\
\text { attribution of } \\
\text { responsibility }\end{array}$ & $\begin{array}{l}\text { Registros module (conformity of management registers) and its } \\
\text { transactions } \\
\text { Regconfop transaction (registers of operator conformity) } \\
\text { Contábil module (accounting conformity) and its transactions } \\
\text { Cadresp module (list of responsible persons) and its transactions }\end{array}$ & $\begin{array}{l}0.858 \\
0.749 \\
0.642 \\
0.547\end{array}$ & 0.906 \\
\hline $\begin{array}{l}\text { F3 - Functionalities } \\
\text { rendering of accounts }\end{array}$ & $\begin{array}{l}\text { Documents subsystem (documents of the SIAFI) and its modules } \\
\text { and transactions } \\
\text { Concredor transaction (creditor consultation) } \\
\text { CPR subsystem (accounts payable and receivable), and its } \\
\text { modules and transactions } \\
\text { Conconta transaction(consultation of the accounting template) }\end{array}$ & $\begin{array}{l}0.780 \\
0.757 \\
0.751 \\
0.600\end{array}$ & 0.883 \\
\hline $\begin{array}{l}\text { F4 - Functionalities } \\
\text { rendering of accounts } \\
\text { about cooperation } \\
\text { agreements }\end{array}$ & Concauc transaction (single list of parties) & $\begin{array}{l}0.903 \\
0.902\end{array}$ & 0.875 \\
\hline
\end{tabular}

The Cronbach's alpha values calculated for the factors involving the level of knowledge indicated the reliability of these factors, as shown in Table 3. The Bonferroni test indicated that the four factors presented a significant difference between the groups $(p<0.05)$. The analysis confirmed that the managers and operators, on average, believe they are more knowledgeable related to factors 1 (functionalities of transparency), 2 (functionalities of attribution of responsibility) and 3 (functionalities of rendering of accounts). Regarding the 
functionalities of factor 4 (rendering of accounts regarding cooperative agreements between government entities), the control agents demonstrated greater knowledge.

\subsection{PERCEPTION OF USERS OF THE HORIZONTAL ACCOUNTABILITY PROMOTED BY THE SIAFI}

In the descriptive analysis, the result indicated that in the questions related to users' perception about transparency, the managers were more optimistic about the contribution of the SIAFI to enable access to public and required information. In turn, the operators more positively assessed the contribution of the SIAFI to enable access to mandatory information with clarity and substance, expressed in accessible language to the target users.

With respect to rendering of accounts, the control agents had a more critical opinion in their assessment of the system to allow the preparation of the accounts of the President of the Republic.

In relation to the contribution of the SIAFI to the attribution of responsibility of public agents, the operators had a more positive opinion regarding identification of the person responsible for administrative actions and the visibility of improprieties committed.

The factor analysis of the variables that compose the perception of users regarding the accountability promoted by the SIAFI presented a KMO value of 0.886 and generated three factors with Cronbach's alpha greater than 0.7, divided exactly as grouped in the questionnaire, corroborating the validity and reliability of these factors.

Table 4 - Factors of the Perception of Accountability Promoted by the SIAFI

\begin{tabular}{|c|c|c|c|}
\hline FACTORS & VARIABLES & $\begin{array}{l}\text { LOADIN } \\
\text { G }\end{array}$ & $\begin{array}{l}\text { ALPH } \\
\text { A }\end{array}$ \\
\hline \multirow{6}{*}{ F1 - Transparency } & Disclosure of useful information to interested parties & 0.820 & \multirow{6}{*}{0.880} \\
\hline & Access to public information & 0.765 & \\
\hline & Information on both positive and negative aspects & 0.739 & \\
\hline & Guarantee of the clarity and substance of information on forms & 0.718 & \\
\hline & Publication of information required by law or regulations & 0.700 & \\
\hline & Language accessible to target users & 0.662 & \\
\hline \multirow{4}{*}{$\begin{array}{l}\text { F2 - Rendering of } \\
\text { accounts }\end{array}$} & $\begin{array}{l}\text { Preparation of the accounts of the President of the Republic } \\
\text { (General Federal Balance Sheet - BGU) }\end{array}$ & 0.841 & \multirow{4}{*}{0.870} \\
\hline & $\begin{array}{l}\text { Preparation of the accounting, financial, budgetary and asset } \\
\text { management statements that compose the accounting process of } \\
\text { public agents }\end{array}$ & 0.817 & \\
\hline & Control of public spending & 0.744 & \\
\hline & Oversight of actions of public agents & 0.684 & \\
\hline \multirow{3}{*}{$\begin{array}{l}\text { F3 - Attribution of } \\
\text { responsibility }\end{array}$} & Visibility of improprieties committed by public agents & 0.832 & \multirow{3}{*}{0.816} \\
\hline & $\begin{array}{l}\text { Identification of the public agent responsible for administrative } \\
\text { actions }\end{array}$ & 0.738 & \\
\hline & $\begin{array}{l}\text { Verification of compliance with the rules contained in the Fiscal } \\
\text { Responsibility Law }\end{array}$ & 0.644 & \\
\hline
\end{tabular}


The Bonferroni test indicated that of the three factors, two presented a significant difference between the groups $(\mathrm{p}<0.05)$. This result confirms that the managers, on average, are more optimistic in relation to factor 1 (transparency promoted by the system), while factor 2 (rendering of accounts) did not present a significant difference with respect to the perception of users, who on average expressed the opinion that the SIAFI makes a large contribution. Regarding attribution of responsibility, the analysis confirmed the more optimistic opinion of the operators. In all the factors, the vision of the control agents was more critical than that of others regarding the contribution of the SIAFI.

We used multiple linear regression to verify the variables influencing the perception of users regarding accountability that the SIAFI can promote:

$\mathrm{FPA}_{\mathrm{i}}=\alpha+\beta_{1} \mathrm{FU}_{1}+\beta_{2} \mathrm{FU}_{2}+\beta_{3} \mathrm{FU}_{3}+\beta_{4} \mathrm{FU}_{4}+\beta_{5} \mathrm{FF}_{1}+\beta_{6} \mathrm{FF}_{2}+\beta_{7} \mathrm{FF}_{3}+\beta_{8} \mathrm{FF}_{4}+\delta_{1} \mathrm{D} 1+\delta_{2} \mathrm{D} 2+$ $\delta_{3} \mathrm{D} 3+\varepsilon \mathrm{i}$

In the equation, $\mathrm{FPA}_{\mathrm{i}}$ denotes the three factors extracted referring to the perception of accountability by the respondents (transparency, rendering of accounts, attribution of responsibility); FU stands for the four factors extracted regarding assessment of the usability of the SIAFI (use of help desk and reports generated by the system, functioning and facility of access and operation, - no need for a SIAFI training course and knowledge of public accounting, flaws in the system); FF are the four factors extracted regarding the level of knowledge of the functionalities of the SIAFI (functionalities of transparency, functionalities of attribution of responsibility, functionalities of rendering of accounts, functionalities of rendering of accounts regarding cooperative agreements between government entities); and D1, D2, D3 and D4 are dummy variables associated with the categorization of the respondents, where D1 denotes the profile of the user (system managers (STN), control agents (CGU and TCU), investigation agents (PCF/DPF), system operators); D2 denotes the level of schooling (high school, bachelor's degree or equivalent, postgraduate specialization, master's or doctorate degrees); D3 denotes the area of training (accounting, economics, law, administration, engineering, others) and D4 denotes the employer (National Treasury Secretariat (STN), Federal Audit Tribunal (TCU), Office of the Comptroller General (CGU), Federal Police Department (DPF), others).

Table 5 presents the regression results: 
Table 5 - Result of the Regression of the Perception of Users Regarding Accountability Promoted by the SIAFI

\begin{tabular}{|c|c|c|c|c|c|c|}
\hline & Factors & $\mathbf{R}^{2}$ & Adj. $R^{2}$ & SD & Coeff. & Sig. \\
\hline 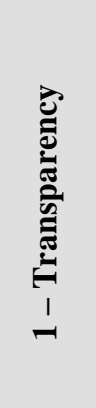 & $\begin{array}{l}\text { Constant } \\
\text { A - Factor } 1 \text { of the system's usability: use of the } \\
\text { help desk and reports of the system } \\
\text { B - Factor } 2 \text { of the system's usability: functioning } \\
\text { and facility of access and operation } \\
\text { C - Users of the SIAFI posted to the TCU } \\
\text { D - Factor } 2 \text { of knowledge of the system: } \\
\text { functionalities of attribution of responsibility }\end{array}$ & 58.9 & 34.6 & $\begin{array}{c}0.53 \\
6\end{array}$ & $\begin{array}{l}1.405 \\
0.301 \\
0.169 \\
-0.281 \\
0.128\end{array}$ & $\begin{array}{l}0.000 \\
0.000 \\
0.000 \\
0.000 \\
0.000\end{array}$ \\
\hline 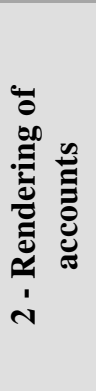 & $\begin{array}{l}\text { Constant } \\
\text { A - Factor } 1 \text { of the system's usability: use of the } \\
\text { help desk and reports of the system } \\
\text { B - Factor } 3 \text { of the system's usability: no need for a } \\
\text { SIAFI training course and training in public } \\
\text { accounting } \\
\text { C - Factor } 4 \text { of the system's usability: flaws in the } \\
\text { system }\end{array}$ & 47.0 & 22.1 & $\begin{array}{c}0.57 \\
3\end{array}$ & $\begin{array}{l}2.042 \\
0.216 \\
0.110 \\
-0.123\end{array}$ & $\begin{array}{l}0.000 \\
0.000 \\
0.000 \\
0.000\end{array}$ \\
\hline 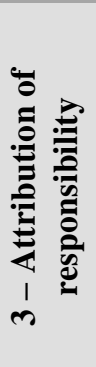 & $\begin{array}{l}\text { Constant } \\
\text { A - Factor } 1 \text { of the system's usability: use of the } \\
\text { help desk and reports of the system } \\
\text { B - Factor } 2 \text { of knowledge of the system: } \\
\text { functionalities of attribution of responsibility } \\
\text { C - Accounting } \\
\text { D - Law }\end{array}$ & 46.5 & 21.6 & $\begin{array}{c}0.59 \\
9\end{array}$ & $\begin{array}{r}2.286 \\
0.225 \\
0.131 \\
-0.219 \\
-0.371\end{array}$ & $\begin{array}{l}0.000 \\
0.000 \\
0.000 \\
0.000 \\
0.000\end{array}$ \\
\hline
\end{tabular}

Notes: Adj. $\mathrm{R}^{2}$ - adjusted R²; SD - standard deviation; Coeff. - coefficients; Sig. - significance.

The variables that were selected in each model were those that had significance better than 0.01 according to Student's t-test.

To compare the various models with different numbers of independent variables in the multiple linear regression, we calculated the adjusted $R^{2}$, since it weights the $R^{2}$ value according to the number of independent variables in the model and the number of observations. The higher the adjusted $\mathrm{R}^{2}$ is, the lower the standard deviation and the better the model at representing the relations between the dependent variable and the independent ones.

As can be seen from table 5, the variability of the dimensions of accountability indicates that $34.6 \%$ of the total variance was explained by the relationship between the independent variables $\mathrm{A} 1, \mathrm{~B} 1, \mathrm{C} 1$ and $\mathrm{D} 1$ and the dependent variable $\mathrm{F} 1 ; 22.1 \%$ by the relationship between the independent variables A2, B2 and C2) and the dependent variable F2; and 21.6\% by the relationship between the independent variables A3, B3, C3 and D3) and the dependent variable F3. 
The analysis of the regression coefficients allows stressing the importance of the facilities of the system to the assessment of its effectiveness, since the perception of accountability related to transparency was higher among users who positively assessed the help desk and report generation resources (factor 1 of usability: use of help desk and system

reports). This is in line with the theoretical expectation of a relationship between the effectiveness or success of systems and their usability (BOKHARI, 2005). However, when considering the influence of the different groups of users, this perception diminished for the users working for the TCU, evidencing the critical view of these civil servants in relation to the system and the existence of multiple populations (or regressions) in the sample, which recommends the use of more statistically sophisticated models to understand their perceptions

The coefficients showed that knowledge of the functionalities of the SIAFI that promote transparency (factor 1 of the level of knowledge: functionalities of transparency) is the factor with greatest influence on the dependent variable, and that users who expressed the opinion that the system has many flaws that are not rectified timely have a lower perception regarding the rendering of accounts promoted by the SIAFI. These results again show the influence of the system's functionality and usability aspects on the perception of its effectiveness.

The equation indicates the stronger influence of the variable A3 (Factor 1 of the system's usability: use of help desk and generation of reports) on the attribution of responsibility permitted by the SIAFI (F3). It also indicates that the training of users in accounting (C3) and law (D3) have an influence, again indicating the non-uniformity in the perception of users - as would be reasonable to suppose - and the need to better understand the evaluation of the subgroups of users of the SIAFI or other information systems. The area of training and schooling level did not influence the perception of accountability related to transparency, rendering of accounts and attribution of responsibility for actions.

The results of the regressions show not only the influence of functionalities and usability of the system on its more general effectiveness, but also indicate the existence of subgroups in the population with distinct expectations and assessments of the system. This brings a new perspective than provided by previous studies that considered the perception of users in aggregate form, such as that by Suzart (2013). However, a better understanding of the dynamic of subgroups within populations requires the use of new statistical techniques, such as latent class growth analysis (LCGA) and growth mixture modeling (GMM). According to Jung \& Wickrama (2008, p. 302), these techniques "have been increasingly recognized for 
their usefulness for identifying homogeneous subpopulations within the larger heterogeneous population and for the identification of meaningful groups or classes of individuals".

\section{CONCLUSION}

The aim of this study was to identify the contribution of the SIAFI in promoting horizontal accountability of the federal public administration in Brazil, based on research of documents and the perception of users of the system, and to assess the characteristics of this system. The first contribution is to expand the scant research on the theme of HÁ in Brazil (OLIVIERI, 2006).

The objective of the investigation was attained by means of operationalization of the definitions and dimensions of accountability according to the theoretical framework, the legal rules in Brazil on application of accountability and examination of the characteristics of the SIAFI in the system's own electronic database, as well as the survey of users' perceptions.

The literature demonstrated that the delineation of the scope of accountability is a longstanding challenge and its translation into the Portuguese language still lacks precision.

The analysis of official documents evidenced that the SIAFI has mechanisms to allow transparency, rendering of accounts and attribution of responsibility within the federal government. It also showed that the system offers resources for control and oversight to other forms of intra-governmental accountability indicated by theoretical works, such as legislative control, judicial control, administrative and financial control and control of results, and indirectly contributes to expand the possibilities for social control.

Analysis of the system's structure and identification of four main groups of users, submitted to the questionnaire in the field survey indicated the perceptions regarding the dimensions associated with horizontal accountability promoted by the SIAFI, namely transparency, rendering of accounts and attribution of responsibility, considering the perception indicators associated with the characterization of users and their assessment of the usability and degree of knowledge of the system.

The result of the study reveals that the users who responded positively to the questions related to the help desk and generation of reports have a better perception of the accountability promoted by the system, showing that the indicator of perception regarding the perception of usability is a determinant in users' perception. This contributes to a better understanding of the previous results found by Suzart (2013), who found low satisfaction levels of end users of the SIAFI - measured by the content, accuracy, format, ease of use and 
timeliness. Additionally, by relating satisfaction measures with other formative variables and with the distinct expectations of users according to their job functions, this study contributes by improving performance measures of this system.

The article also provides evidence that the usability of the system is related to user satisfaction, by analyzing variables that act as moderators in the relationship and that can affect its magnitude (BOKHARI, 2005), such as time spent by the user working in public service, position held and use of the system. Furthermore it shows the influence of variables related to the posting of the civil servants and their educational background on their perception of the system's effectiveness. This points to the need to use more sophisticate statistical models that allow understanding the expectations of these subpopulations not only for the SIAFI, but for assessment of management systems in general.

A limitation of the results that can limit generalization and requires caution in interpretation is the non-random nature of the sample and the self-selection bias. These problems are not uncommon in management surveys and cannot be overcome by increasing the sample size, instead requiring techniques to select subjects that are not always applicable in practice. Although the sample was small in proportion to the universe, the 287 responses was an acceptable number for the statistical treatments applied, and the relative order of size of the user categories was reflected in the sample.

New models of government action have required strengthening the capability to deal with the growing complexity and fragmentation of society's demands, be it in the articulation of the networks of governmental and non-governmental actors involved or the speed to respond to these demands. As a consequence, the vertical or hierarchical model of accountability is insufficient to overcome the growing information asymmetry between society and government, and even between the latter's various levels. Horizontal accountability, by strengthening the system of vigilance, monitoring and attribution of responsibility between peers or between distinct public organizations, is an effective and necessary response to this new context. In this respect, the SIAFI and other intragovernmental control and information systems are fundamental for consolidation of this form of accountability.

Out aim with this study was to promote the effectiveness of HÁ, by identifying the strengthes and weaknesses perceived in the SIAFI, based both on the literature and the perception of its users. The results can contribute to other studies that investigate questions related to the integration of the SIAFI with other structuring systems of the Brazilian 
government, such as the Integrated System for General Services Administration (SIASG), the Integrated System for Planning and Budget (SIOP) and the Cost Information System (SIC).

In light of the new scenario of (vertical) accountability provided by the Information Access Law (Law 12,527/2011), it is important to mention that the information asymmetries between civil society and the public administration combined with the difficulty of establishing references for comparison can limit its effectiveness. What information should be requested from public entities? What should be the elements for comparison? How can mechanisms for attribution of responsibility and enforcement be brought to bear? Strengthening of the SIAFI by bringing elements for comparison and attribution of responsibility, and possibly facilitating access to the system, should be considered to assure more effectiveness application of the law. As discussed in this article, consolidating both the vertical and horizontal dimensions of accountability is necessary for Brazilian society to have an adequate translation (or comprehension) of the concept. Future studies could focus on the complementarity of these two instruments for promotion of accountability in the country.

Finally, another extension of this study would be to analyze the attributions developed by the civil servant users of the structuring systems, the integration of these systems in promoting HÁ and how the training of public agents in the use of these systems can contribute to accountability in the Brazilian federal public administration.

\section{REFERENCES}

ABRUCIO, L. F.; LOUREIRO, M. R. Finanças públicas, democracia e accountability. In: BIDERMAN, Ciro; ARVATE, Paulo (Orgs.). Economia do setor público no Brasil. Rio de Janeiro: Elsevier, 2005.

AMIRKHANYAN, A. A. What is the effect of performance measurement on perceived accountability effectiveness in state and local government contracts? Public Performance \& Management Review, v. 35, n. 2, p. 303-339, dec. 2011.

ANASTASIA, F.; MELO, C. R. F. Accountability, representação e estabilidade política no Brasil. In: O Estado numa era de reformas: os anos FHC: parte 1. Brasília, 2002. v. 7. (Coleção Gestão Pública). Disponível em: $<$ http://www.eaesp.fgvsp.br/subportais/ceapg/Acervo\%20Virtual/Cadernos/Cadernos/Cad47.p df $\geq$. Acesso em: 17 out. 2012.

BOKHARI, R. H. The relationship between system usage and user satisfaction: a metaanalysis. Journal of Enterprise Information Management, v. 28, n. 2, 2005.

BOVENS, M. Public accountability. In: FERLIE, E.; LYNN JR., L. E.; POLLITT, C. (Eds.). The Oxford handbook of public management. Oxford: Oxford University Press, 2005. Chapter 8, p. 182-208. 
BRAHMA, S. S. Assessment of construct validity in management research. Journal of Management Research, v. 9, n.2, p. 59-71, aug. 2009.

BRASIL. Lei n ${ }^{\circ}$ 9.755, de 16 de dezembro de 1998. Dispõe sobre a criação de "homepage" na "Internet", pelo Tribunal de Contas da União, para divulgação dos dados e informações que especifica, e dá outras providências. Diário Oficial da União de 17 de dezembro de 1998.

Lei $\mathrm{n}^{\circ}$ 9.784, de 29 de janeiro de 1999. Regula o processo administrativo no âmbito da Administração Pública Federal. Diário Oficial da União de $1^{\circ}$ de fevereiro de 1999 , retificado no Diário Oficial da União de 11 de março de 1999.

Lei Complementar $\mathrm{n}^{\circ} 101$, de 4 de maio de 2000. Estabelece normas de finanças públicas voltadas para a responsabilidade na gestão fiscal e dá outras providências. Diário Oficial da União de 5 de maio de 2000a.

Constituição da República Federativa do Brasil: promulgada em 5 de outubro de 1988. Coleção Saraiva de Legislação. 44.ed. atual. e ampl. São Paulo: Saraiva, 2010b.

Ministério da Fazenda. Secretaria do Tesouro Nacional. Manual de demonstrativos fiscais: aplicado à União e aos Estados, Distrito Federal e Municípios. 3. ed. Brasília : Coordenação-Geral de Contabilidade, 2010c.

BRESSER-PEREIRA, L. C. Reforma do Estado para a cidadania: a reforma gerencial brasileira na perspectiva internacional. São Paulo: Ed. 34; Brasília: ENAP, 1998.

CAMPOS, A. M. M. Accountability: quando podemos traduzi-la para o português? Revista de Administração Pública. Rio de Janeiro, ano 24, n. 2, p. 33, fev./abr. 1990.

CASTRO, D. P.; GARCIA, L. M. Contabilidade pública no Governo Federal: guia para reformulação do ensino e implantação da lógica do SIAFI nos governos municipais e estaduais com utilização do Excel. 2 ed. São Paulo: Atlas, 2008.

Auditoria, contabilidade e controle interno no setor público: integração das áreas do ciclo de gestão: contabilidade orçamento e auditoria e organização dos controles internos, como suporte à governança corporativa. 3. ed. São Paulo: Atlas, 2010.

CASTRO, R. G.; GOMES, L. S. Administração financeira e orçamentária. 7. ed. Brasília: Vestcon, 2002.

CENEVIVA, R.. Accountability: novos fatos e novos argumentos: uma revisão da literatura recente. In: ENCONTRO DE ADMINISTRAÇÃO PÚBLICA E GOVERNANÇA DA ANPAD (ENAPG), 2006, São Paulo (SP). Anais... São Paulo: ANPAD, 2006.

COELHO, S. C. T. Terceiro setor: um estudo comparado entre Brasil e Estados Unidos. São Paulo: Senac, 2000.

DELONE, W. H.; MCLEAN, E. R. Information systems success: the quest for the dependent variable. Information Systems Research, v. 3, n. 1, p. 60-95, 1992.

GARLAND, R. The mid-point on a rating scale: is it desirable? Marketing Bulletin, v. 2, p. 66-70, 1991. Disponível em: 〈http://marketing-bulletin.massey.ac.nz〉. Acesso em: 28 out.

2012. 
HAIR JUNIOR, J. F. Análise multivariada de dados. Porto Alegre: Bookman, 2005.

HINKIN, T. R. A brief tutorial on the development of measures for use in survey questionnaires. Organizational Research Methods, v. 1, n.1, p. 104-121, jan. 1998.

IBGC. Instituto Brasileiro de Governança Corporativa. Código das melhores práticas de governança corporativa. 4. ed. São Paulo, SP : IBGC, 2009. Disponível em: <http://www.ibgc.org.br/CodigoMelhoresPraticas.aspx>. Acesso em: 24 nov. 2010.

JUNG, T.; WICKRAMA, K. A. S. An introduction to latent class growth analysis and growth mixture modeling. Social and Personality Psychology Compass, v. 2, n. 1, p. 302-317, 2008.

LIMA, D. V.; CASTRO, R. G. Contabilidade pública: integrando União, Estados e Municípios: SIAFI/Siafem. 3. ed. São Paulo: Atlas, 2007.

LOUZADA, S. V.; FONTES FILHO, J. R.; REZENDE, J. F. C. O uso da internet para promoção da accountability pelas Empresas Estatais Federais Brasileiras. In: ENCONTRO DE ADMINISTRAÇÃO PÚBLICA E GOVERNANÇA DA ANPAD, 2010, Vitória (ES). Anais... Vitória: ANPAD, 2010.

MALHOTRA, N. K. Pesquisa de marketing: uma orientação aplicada. 3. ed. Porto Alegre: Bookman, 2001.

MARTINS JÚNIOR, W. P. Transparência administrativa, publicidade, motivação e participação popular. São Paulo: Saraiva, 2004.

MASONER, M. M.; LANG, S. S.; MELCHER, A. J. A meta-analysis of information system success: a reconsideration of its dimensionality. International Journal of Accounting Information Systems, v. 12, n. 1, p. 136-141, jun. 2011.

MOSHER, F. Democracy and the public service. New York: Oxford University, 1968.

O’DONNELL, G. Accountability horizontal e novas poliarquias. Revista Lua Nova. São Paulo, n. 44, 1998.

Horizontal accoutability in new democracies. In: SCHEDLER, A. DIAMOND, L.; PLATTNER, M. F. (Eds.). The self-estraining state: power and accountability in new democracies. Boulder and London: Lynne Rienner Publishers, 1999.

OLIVIERI, C. O controle interno como instrumento de accountability horizontal: uma análise exploratória da controladoria geral da união. In: ENCONTRO DE ADMINISTRAÇÃO PÚBLICA E GOVERNANÇA (ENAPG), 2., 2006, São Paulo (SP). Anais... São Paulo: ANPAD, 2006.

OSBORNE, S. P. The new public governance. Public Management Review, v. 8, n. 3, p. 377-387, 2006.

PETTER, S.; DELONE, W.; MCLEAN, E. R. The past, present, and future of "IS success". Journal of the Association for Information Systems, v. 13, n. 5, p. 341-362, maio 2012. 
PINHO, J. A. G.; SACRAMENTO, A. R. S. Accountability: já podemos traduzi-la para o português? Revista de Administração Pública, Rio de Janeiro, v. 43, n. 6, nov./dez. 2009.

PISCITELLI, R. B.; TIMBÓ, M. Z. F. Contabilidade pública: uma abordagem da administração financeira pública. 11. ed. São Paulo: Atlas, 2010.

PRZEWORSKI, A. Sobre o desenho do Estado: uma perspectiva agente x principal. Reforma do Estado e Administração Pública Gerencial, 7. ed. Rio de Janeiro: FGV,2005. p. 39-74.

RIBEIRO FILHO, J. F. Controle gerencial para entidades da administração pública. 2010. 74 p. Monografia - Escola de Administração Fazendária (ESAF), Brasília (DF), 1997. Disponível em: <http://www.tesouro.fazenda >. Acesso em: 29 out. 2010.

ROMZEK, B. S.; JOHNSTON, J. M. State social services contracting: exploring the determinants of effective contract accountability. Public Administration Review, v. 65, n. 4, p. 436-449, jul./aug. 2005.

SACRAMENTO, A. R. S. Contribuições da Lei de Responsabilidade Fiscal para o avanço da accountability no Brasil. Cadernos Gestão Pública e Cidadania (CEAPG), São Paulo, v. 10, n. 47, 2005.

SCHILLEMANS, T. Accountability in the shadow of hierarchy: the horizontal accountability of agencies. Public Organization Review, v. 8, n. 2, p. 175-194, jun. 2008.

SLOMSKI, V. Manual de contabilidade pública: um enfoque na contabilidade municipal. 2. ed. São Paulo: Atlas, 2003.

SUZART, J. A. S. End-user satisfaction with the integrated system of the Federal Government financial administration (SIAFI): a case study. JISTEM - Journal of Information Systems and Technology Management, v. 10, n. 1, p. 145-160, jan./apr. 2013.

VALENTE, A. P. A. Transparência e opacidade: o SIAFI no acesso à informação orçamentária. Belo Horizonte: Annablume, 2004.

WEBER, E. The question of accountability in historical perspective: from Jackson to contemporary grassroot ecosystem management. Administration \& Society, v. 31, n. 4, p. 451-494, sep. 1999.

ZANELLO, G.; MAASSEM, P. Strengthening citizen agency and accountability through ICT: an extrapolation for Eastern Africa. Public Management Review, v. 13, n. 3, p. 363$382,2011$.

\section{APPENDIX}

Questionnaire script:

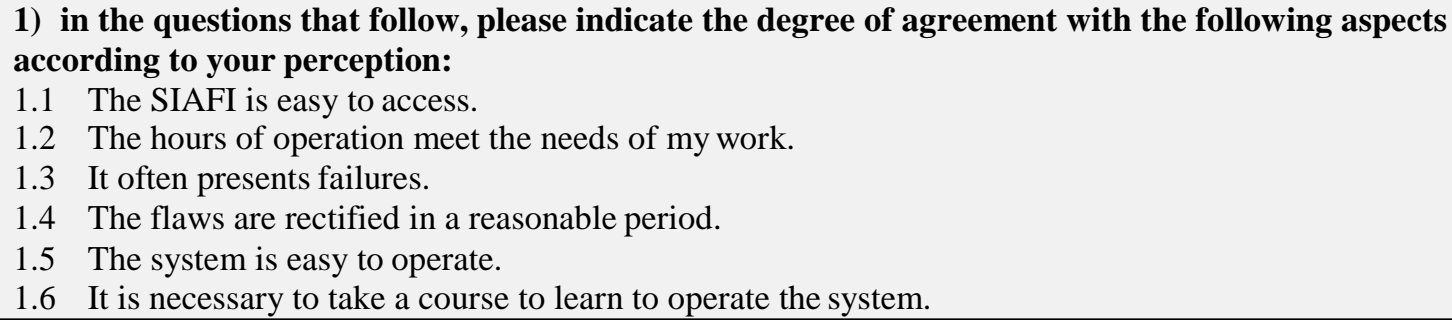



1.7 It is not necessary to have knowledge of public accounting to operate it.
1.8 The structured reports meet the needs of my work.
1.9 It's easy to produce reports in the SIAFI.
1.10 I often use the SIAFI Management to produce unstructured reports.
1.11 The SIAFI Web Manual answers most of my doubts.
1.12 The online help desk responds to my doubts promptly.

2) How do you assess your knowledge in relation to the functionalities of the SIAFI (subsystems, modules and transactions), regarding the capacity to contribute to transparency of the public administration?

2.1 Password subsystem, its modules and transactions

2.2 Regconfop transaction (registers of operator conformity)

2.3 Conconta transaction(consultation of the accounting template)

2.4 Demonstra module (accounting statements) and its transactions

2.5 Documents subsystem (documents of the SIAFI) and its modules and transactions 2.6

module (accounting conformity) and its transactions

Contábil

2.7 Registros module (conformity of management registers) and its transactions

2.8 Concontir transaction (consultation of accounts to regularize

2.9 Conincons transaction (consultation of inconsistencies - others)

2.10 Conevento transaction (event consolation)

2.11 Sintéticos module (synthetic consultations) and its transactions

3) How do you assess your knowledge in relation to the functionalities of the SIAFI (subsystems, modules and transactions), regarding the capacity to contribute to rendering of accounts of the public administration?

3.1 Conconta transaction(consultation of the accounting template)

3.2 Demonstra module (accounting statements) and its transactions

3.3 Documents subsystem (documents of the SIAFI) and its modules and transactions

3.4 Conevento transaction (event consolation)

3.5 Concredor transaction (creditor consultation)

3.6 CPR subsystem (accounts payable and receivable), and its modules and transactions

3.7 Concauc transaction (single list of parties)

3.8 Cadastro module (transfer list) and its transactions

4) How do you assess your knowledge in relation to the functionalities of the SIAFI (subsystems, modules and transactions), regarding the capacity to contribute to attribution of responsibility for actions of public agents?

4.1 Demonstra module (accounting statements) and its transactions

4.2 Contábil module (accounting conformity) and its transactions

4.3 Registros module (conformity of management registers) and its transactions

4.4 Concontir transaction (consultation of accounts to regularize)

4.5 Conincons transaction (consultation of inconsistencies - others)

4.6 Cadresp module (list of responsible persons) and its transactions

In questions 5 to 7, please indicate the level of contribution offered by the SIAFI in promoting accountability in each subcategory.

5) Category and subcategories of the transparency dimension - What is the contribution of the SIAFI to enable?:

5.1 Access to public information

5.2 Disclosure of useful information to interested parties

5.3 Publication of information required by law or regulations

5.4 Guarantee of the clarity and substance of information on forms

5.5 Accessible language to the target users

5.6 Information on both positive and negative aspects

5.7 Information in real time

5.8 Reliability of the information provided

6) Category and subcategories of the rendering of accounts dimension - What is the contribution of the 
SIAFI to enable?:

6.1 Preparation of the accounting, financial, budgetary and asset management statements that compose the accounting process of public agents

6.2 Preparation of the accounts of the President of the Republic (General Federal Balance Sheet - BGU)

6.3 Control of public spending

6.4 Oversight of actions of public agents

7) Category and subcategories of the attribution of responsibility dimension: What is the contribution of the SIAFI to enable?:

7.1 Identification of the public agent responsible for administrative actions

7.2 Verification of compliance with the rules contained in the Fiscal Responsibility Law

7.3 Visibility of improprieties committed by public agents 